\title{
Acid-shock responses in Staphylococcus aureus investigated by global gene expression analysis
}

\author{
Correspondence \\ Askild Holck \\ askild.holck@matforsk.no
}

Received 10 January 2007

Revised 16 March 2007

Accepted 19 March 2007

\section{Erlend Bore, ${ }^{1,2}$ Solveig Langsrud, ${ }^{1}$ Øyvind Langsrud, ${ }^{1}$ Tone Mari Rode ${ }^{1,2}$ and Askild Holck ${ }^{1}$}

\author{
${ }^{1}$ Matforsk, Norwegian Food Research Institute, Osloveien 1, N-1430 Ås, Norway \\ ${ }^{2}$ The Norwegian University of Life Sciences (UMB), PO Box 5003, N-1432 Ås, Norway
}

\begin{abstract}
A general overview is presented of the changes in the genetic expression along a time curve through the first 20 min after acidification to $\mathrm{pH} 4.5$ of exponentially growing cultures of the food pathogenic strain Staphylococcus aureus 50583. A newly developed method for statistical significance testing was used to detect significant gene expression responses. Most responses showed an increase or decrease from time zero to $10 \mathrm{~min}$ after acidification, and then generally a stabilization in expression level from 10 to $20 \mathrm{~min}$. Increased urease activity appeared to be an important factor in the acid defence, along with proton excretion by NADH dehydrogenase and macromolecule repair mechanisms. Oxidative-stress responses, such as increased expression of thioredoxin genes and upregulation of pentose phosphate pathway genes to generate more reducing power, were also induced. A general reduction in the expression of genes encoding ribosomal proteins and genes involved in nucleotide synthesis, as well as fatty acid and lipoprotein metabolism, reflected the lowered growth rate after acidification. The $\mathrm{pH}$ shock did not appear to trigger major virulence responses or biofilm formation. Metal ion regulation and transport were affected by the acid shock, and production of several cofactors such as molybdopterin was increased. Many of the presented observations could be explained, while some represent still-unknown mechanisms. The patterns of regulation were confirmed by quantitive reverse transcriptase PCR (QRT-PCR). Together, these results showed the main responses of $S$. aureus and will be a good starting point for future, more specific, in-depth studies of specific gene responses that occur in conjunction with the acid-stress defence of $S$. aureus.
\end{abstract}

\section{INTRODUCTION}

Staphylococcus aureus is a major human pathogen that causes a wide spectrum of infections, ranging from superficial wound infections to life-threatening septicaemia and toxic-shock syndrome (Lowy, 1998). It is also a major food poisoning bacterium posing a great risk to consumer health, mainly through its production of heat-stable enterotoxins. S. aureus is considered to be a poor competitor in complex microbial populations. Therefore, the greatest risk of staphylococcal food poisoning is associated with food

Abbreviations: CAl, codon adaptation index; 6-FAM, 2',7'-bis(2carboxyethyl)-5(6)-carboxyfluorescein; FDR, false-discovery rate; PPP, pentose phosphate pathway; QRT-PCR, quantitative reverse transcriptase PCR; TAMRA, tetramethyl-6-carboxyrhodamine; TCA cycle, tricarboxylic acid cycle.

The array data discussed in this publication have been deposited in the NCBI Gene Expression Omnibus (GEO; http://www.ncbi.nlm.nih.gov/ geo/) and are accessible through GEO series accession number GSE7273.

A complete table showing genes up- and down-regulated in $S$. aureus after acid shock is available with the online version of this paper. contaminated with $S$. aureus after the normal microflora has been destroyed. Although $S$. aureus is found in many environments, the source of contamination is often human, since a large part of the healthy human population carry the bacteria as part of the normal microflora associated with the nose, throat and skin.

This work constitutes a part of our effort to study different stress responses of $S$. aureus in food. Acidification is one of the major ways to reduce growth of bacteria in food processing, and $S$. aureus is quite acid tolerant. In general, bacteria possess a multitude of defence mechanisms to cope with a sudden drop in $\mathrm{pH}$ (for a review for Grampositive bacteria, see Cotter \& Hill, 2003). The most direct approach is the use of proton pumps, which literally pump protons out of the cell to keep the internal $\mathrm{pH}$ at an acceptable level. Another approach is to increase the concentration of alkaline compounds within the cell to counteract the acidification of the cytoplasm. Repair mechanisms are needed due to an increased rate of damage to macromolecules. Biofilm formation can also affect the acid resistance of the cells. Energy metabolism and 
metabolic pathways are altered by the shift of energy usage from mainly growth to defence mechanisms.

In contrast to the situation for Escherichia coli, much less is known about the general stress responses in $S$. aureus. Although some studies have shown the involvement of specific genes or genetic systems, few overall studies have elucidated the general mechanisms employed by $S$. aureus to cope with acidic environments. Most published work on how S. aureus, or similar bacteria such as Streptococcus, responds to low $\mathrm{pH}$ have chosen a steady-state approach, studying growth at low $\mathrm{pH}$ in parallel with growth under neutral-pH conditions (Len et al., 2004; Weinrick et al., 2004; Wilkins et al., 2002). In this work, we have chosen to focus on the genetic expression of a food poisoning $S$. aureus strain along a time curve through the first $20 \mathrm{~min}$ after a sudden acid stress to $\mathrm{pH} 4.5$ of exponentially growing cultures. By using a microarray approach in combination with a novel improved statistical analysis, we aspire to give a general overview of how this important pathogen responds to cope with this sudden change of environmental conditions.

\section{METHODS}

Strain and growth conditions. S. aureus 50583 used for this work was a gift from the Norwegian Veterinary Institute, and was isolated from a foodborne outbreak in which the source of infection was traced to a pizza. The strain identity was confirmed as $S$. aureus by $16 \mathrm{~S}$ rDNA sequencing. The active toxin was classified as toxin $\mathrm{B}$. Bacteria were stored at $-80{ }^{\circ} \mathrm{C}$ in TSB medium supplemented with $15 \%$ glycerol. Precultures of S. aureus 50583 were prepared by inoculation of frozen glycerol culture to $1 \mathrm{ml}$ Tryptic Soy Broth (TSB; Oxoid) and incubation overnight at 200 r.p.m. and $37{ }^{\circ} \mathrm{C}$. The precultures were transferred to $99 \mathrm{ml}$ TSB in $500 \mathrm{ml}$ baffled shake flasks and incubated at 200 r.p.m. and $37{ }^{\circ} \mathrm{C}$. At an $\mathrm{OD}_{600}$ of 1.0 , corresponding to $10^{8}$ c.f.u. $\mathrm{ml}^{-1}$, control samples were withdrawn immediately prior to the addition of $450-500 \mu \mathrm{l} 6.5 \mathrm{M} \mathrm{HCl}$, which directly brought the $\mathrm{pH}$ down to $4.5 \pm 0.1$. Samples were withdrawn 2, 5, 10 and $20 \mathrm{~min}$ after addition of acid. All samples were directly transferred to RNAprotect Bacteria Reagent (Qiagen).

This procedure was repeated on three different days for a total of three sample sets (in parallel). Separate array experiments were performed on all three parallel sample sets.

RNA extraction. Total RNA was extracted by using the RNeasy Protect Bacteria Mini Prep kit (Qiagen). Briefly, $1.5 \mathrm{ml}$ bacterial culture was added directly to $3 \mathrm{ml}$ RNAprotect Bacteria Reagent, vortexed for $5 \mathrm{~s}$, incubated at room temperature for $5 \mathrm{~min}$ and then centrifuged at $10000 \mathrm{~g}$ for $10 \mathrm{~min}$ at room temperature. The supernatant was discarded and the pellet resuspended in $40 \mu \mathrm{l}$ Tris/ EDTA buffer followed by addition of $50 \mu$ lysozyme stock solution $\left(40 \mathrm{mg} \mathrm{ml}^{-1}\right)$ and $10 \mu$ lysostaphin stock solution $\left(1 \mathrm{mg} \mathrm{ml}^{-1}\right)$. The samples were incubated at $37^{\circ} \mathrm{C}$ with shaking for $10 \mathrm{~min}$. The manufacturer's protocol, including use of kit buffers, was followed from this point. RNase-free water was added to the membrane of the RNeasy Mini Spin column (Qiagen), and after 1 min incubation at room temperature the RNA was eluted by centrifugation of the column at $10000 \mathrm{~g}$ for $1 \mathrm{~min}$. The concentration and purity of the total RNA were analysed with an Ultrospec 3000 spectrophotometer (Pharmacia Biotech) and the RNA 600 Nano LabChip system (Agilent Technologies).
Labelling of total RNA and microarray hybridization. S. aureus genome microarrays (version 1) were kindly provided by The Institute for Genomic Research (TIGR). The slides contained PCR products of 2576 ORFs from S. aureus COL. In addition the arrays contained 117 unique ORFs from strains Mu50 (60), MW2 (51) and N315 (6). Total RNA was reverse-transcribed by using random hexamers in the presence of aminoallyl-dUTP, followed by labelling with Cy3 and Cy5 monoreactive dyes (TIGR protocol, standard operating procedure no. M007; http://pfgrc.tigr.org/protocols/ M007.pdf). Briefly, $2 \mu \mathrm{g}$ total RNA and $6 \mu \mathrm{g}$ random hexamers (Invitrogen) in a reaction volume of $18.5 \mu \mathrm{l}$ were denatured at $70{ }^{\circ} \mathrm{C}$ for $10 \mathrm{~min}$, snap-cooled on ice for $30 \mathrm{~s}$ and centrifuged briefly to bring down condensation. Then $6 \mu$ First Strand buffer (Invitrogen), $3 \mu \mathrm{l} 0.1 \mathrm{M}$ DTT, $1.2 \mu \mathrm{l} 12.5 \mathrm{mM}$ deoxynucleoside triphosphateaminoallyl-dUTP labelling mix (Invitrogen) and 400 U Superscript II reverse transcriptase (Invitrogen) were added. The labelling reaction mixture was incubated at $42{ }^{\circ} \mathrm{C}$ overnight. The first-strand synthesis reaction was stopped by adding $10 \mu \mathrm{l} 0.5 \mathrm{M}$ EDTA and $10 \mu \mathrm{l} 1 \mathrm{M}$ $\mathrm{NaOH}$. The reaction mixture was incubated at $65{ }^{\circ} \mathrm{C}$ for $15 \mathrm{~min}$, and then $25 \mu \mathrm{l} 1 \mathrm{M}$ Tris/ $\mathrm{HCl}(\mathrm{pH} 7.0)$ was added. The removal of unincorporated aminoallyl-dUTP and free amines was performed according to the TIGR protocol with the Qiagen QIAquick PCR purification kit. After being dried in a Speed Vac (Savant), the samples were stored at $-80{ }^{\circ} \mathrm{C}$. Coupling of aminoallyl-labelled cDNA to CyDye Ester (Amersham Biosciences) was done according to the TIGR protocol. The eluted Cy3- and Cy5-labelled samples were mixed and dried in a Speed Vac. The hybridization of the labelled cDNA probes was performed according to a protocol from TIGR (standard operating procedure no. M008; http://pfgrc.tigr.org/protocols/M008.pdf). Briefly, slides were incubated in a preheated prehybridization buffer $[5 \times \mathrm{SSC}(1 \times \mathrm{SSC}$ is $0.15 \mathrm{M} \mathrm{NaCl}, 0.015 \mathrm{M}$ sodium citrate), $0.1 \% \mathrm{SDS}, 1 \% \mathrm{BSA}$, at $42{ }^{\circ} \mathrm{C}$ for at least $1 \mathrm{~h}$. After prehybridization, the slides were washed in distilled water (five times $2 \mathrm{~min}$ in $50 \mathrm{ml}$ tubes) and then in $50 \mathrm{ml}$ isopropanol. The slides were dried by centrifugation at $90 \mathrm{~g}$ for $12 \mathrm{~min}$ at room temperature. The dried Cy3- and Cy5-labelled cDNA was resuspended in $60 \mu \mathrm{l}$ hybridization buffer ( $50 \%$ formamide, $5 \times$ SSC, $0.1 \%$ SDS, $300 \mu \mathrm{g}$ salmon sperm DNA), denatured at $95{ }^{\circ} \mathrm{C}$ for $5 \mathrm{~min}$, vortexed at low speed and heated again at $95{ }^{\circ} \mathrm{C}$ for $5 \mathrm{~min}$. The sample was centrifuged briefly and applied to the prehybridized microarray under a coverslip (LifterSlip, Erie Scientific). The slides were placed in a waterproof hybridization chamber for hybridization in a $42{ }^{\circ} \mathrm{C}$ water bath overnight. After hybridization, the slides were washed in $2 \times$ SSC buffer with $0.1 \%$ SDS $\left(55{ }^{\circ} \mathrm{C}, 2 \mathrm{~min}\right)$, then washed in $0.1 \times$ SSC with $0.1 \%$ SDS buffer (room temperature, $2 \mathrm{~min}$ ), followed by two washes in $0.1 \times$ SSC buffer (room temperature, $2 \mathrm{~min}$ ). The slides were dried by centrifugation at $90 \mathrm{~g}$ at room temperature for $12 \mathrm{~min}$.

\section{Reverse transcription and quantitative reverse transcriptase} PCR (QRT-PCR). Total RNA was reverse-transcribed by using random primers. The reaction mixture $(20 \mu \mathrm{l})$, containing $300 \mathrm{ng}$ total RNA, $100 \mathrm{ng}$ random primers (Invitrogen) and $1 \mu \mathrm{l} 10 \mathrm{mM}$ dNTP mix in a reaction volume of $13 \mu \mathrm{l}$, was denatured at $65{ }^{\circ} \mathrm{C}$ for $5 \mathrm{~min}$, snap-cooled on ice and centrifuged briefly. Then $4 \mu \mathrm{l} 5 \times$ First Strand buffer (Invitrogen) and $2 \mu \mathrm{l} 0.1 \mathrm{M}$ DTT were added and the

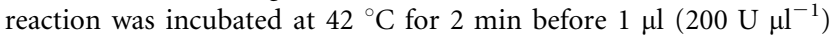
SuperScript II reverse transcriptase (Invitrogen) was added. The reaction was incubated at $25{ }^{\circ} \mathrm{C}$ for $10 \mathrm{~min}$ and $42{ }^{\circ} \mathrm{C}$ for $50 \mathrm{~min}$. The reaction was centrifuged briefly and incubated at $70{ }^{\circ} \mathrm{C}$ for $15 \mathrm{~min}$ before being centrifuged briefly again. cDNA was synthesized from two biological parallel samples grown on different days. Three reverse-transcriptase reactions were made for each biological replicate sample of RNA in addition to one negative control (without enzyme). After the reverse-transcriptase reaction, the cDNA was added in $30 \mu \mathrm{l}$ $\mathrm{H}_{2} \mathrm{O}$, and $1.5 \mu \mathrm{l}$ was used as template in the QRT-PCR analyses. Primers and probes (Table 1) were designed using Primer Express 
Table 1. Primers and probes used in QRT-PCR expression studies

\begin{tabular}{|c|c|c|c|}
\hline TIGR locus & Gene $^{\star}$ & Name & Sequence $\left(5^{\prime}-3^{\prime}\right) \dagger$ \\
\hline \multirow[t]{3}{*}{ SA2280 } & ureA & UreaF & TTGTAGTGGCGGCGGAAG \\
\hline & & UreaR & TGCCTCAGGATGATTTAGTTTCAA \\
\hline & & UreApr & TGCACGTCGTCGTAAAGCACGTGG \\
\hline \multirow[t]{3}{*}{ SA2282 } & ureC & UrecF & GTGGTACTGGTGCTTCAGAAGGT \\
\hline & & UreCR & CGGCAGCTTCTAACATTCTATGAAT \\
\hline & & UreCpr & AGCAACAACTGTAACTCCAGGTCCATGGC \\
\hline \multirow[t]{3}{*}{ SA2284 } & ureF & UreFF & ACACACTTAAGATTATTTCAGTTCTGTGATT \\
\hline & & UreFR & TTCGTTGAATATATGTTTCAAGACCAA \\
\hline & & UreFpr & ACAGTTTCCAACAGGTGCTTTCAGTCATTCA \\
\hline \multirow[t]{3}{*}{ SA2654 } & $\operatorname{arcC2}$ & $\operatorname{ArcC} 2 \mathrm{~F}$ & CGCCGGCAATGCCA \\
\hline & & $\operatorname{ArcC} 2 \mathrm{R}$ & CAGTTTCCAACCAATAGCCTATCA \\
\hline & & ArcC2pr & TGGATACTTGTGGTGCAATGTCACAGGG \\
\hline \multirow[t]{3}{*}{ SA0494 } & nuоF & NuoFF & GATTGAATCTGTAACDGCACCA \\
\hline & & NuoFR & ACCACCTGCATTCACAATTCC \\
\hline & & NuoFpr & CGCCAGTATCGGCAATTATGCATGC \\
\hline \multirow[t]{3}{*}{ SA2097 } & $\operatorname{atp} A$ & AtpAF & GACGTTATGGCTGGTGAGCTAGT \\
\hline & & AtpAR & CACACCCACGTTTGACTCTTCA \\
\hline & & AtpApr & AATTCCATAACGGCGTACTTGGTTTAGCCC \\
\hline \multirow[t]{3}{*}{ SA1549 } & $z w f$ & ZwfF & CAAACACATCCCWTGTTTAATCACA \\
\hline & & ZwfR & TGGAATATTGATGGAAACAACTTACG \\
\hline & & Zwfpr & TCTTTGGTGCAACTGGTGACTTAAGCC \\
\hline \multirow[t]{3}{*}{ Sa2178 } & Sa2178 & SA2178 F & GGTCTGCTTGATATTGGACAACC \\
\hline & & SA2178R & ACTGAACCTACAGCACCAGATGC \\
\hline & & SA2178pr & AAAGCCGGTGATACTGTTGTGGTTTCAGC \\
\hline \multirow[t]{3}{*}{ SA1368 } & katA & KatAF & AACCGAAATGTTTGCCCGT \\
\hline & & KatAR & ATGTCACGCTCCGCATCA \\
\hline & & KatApr & TCTCTACTGTAGCAGGAGAACGTGGTGCTG \\
\hline \multirow[t]{3}{*}{ SACOL_Sa16SA $\ddagger$} & $16 S$ & $16 \mathrm{SF} 2$ & CCAGCAGCCGCGGTAAT \\
\hline & & 16SR2 & CGCGCTTTACGCCCAATA \\
\hline & & 16SFpr & CGTAGGTGGCAAGCGTTATCCGGA \\
\hline \multirow[t]{3}{*}{ SA0005 $\ddagger \S$} & gyrB & GyrBF2 & AGTAACGGATAACGGACGTGGTA \\
\hline & & GyrBR2 & CCAACACCATGTAAACCACCAGAT \\
\hline & & GyrBpr & CCGCCACCGCCGAATTTACCACCA \\
\hline
\end{tabular}

${ }^{\star}$ Gene sequences from S. aureus COL accession no. NC002951.

$\dagger$ Primers were consensus primers for the known S. aureus sequences. All probes were labelled with 6-FAM at the $5^{\prime}$ end and TAMRA at the $3^{\prime}$ end.

¥Used as reference genes.

§Design from Beenken et al. (2004).

(version 1.0) ABI PRISM (Applied Biosystems) software. The probes contained 2',7'-bis(2-carboxyethyl)-5(6)-carboxyfluorescein (6-FAM) linked to the $5^{\prime}$ end, and tetramethyl-6-carboxyrhodamine (TAMRA) at the $3^{\prime}$ end. Amplification efficiency was analysed by performing PCR on dilution series of DNA. The amplification reaction mixture $(25 \mu \mathrm{l})$ contained: $1.5 \mu \mathrm{l}$ template cDNA (1000-fold diluted for the 16S PCR); $1 \times$ TaqMan buffer A; $5 \mathrm{mM} \mathrm{MgCl}_{2} ; 200 \mu \mathrm{M}$ each of dATP, dCTP and dGTP, and $400 \mu \mathrm{M}$ dUTP; $80 \mu \mathrm{M}$ AmpErase uracil $N$-glycosylase; $0.2 \mu \mathrm{M}$ forward and reverse primer; $0.1 \mu \mathrm{M}$ MGB probe; and $1.25 \mathrm{U}$ AmpliTaq Gold DNA polymerase (Applied Biosystems). Before amplification, the reaction mixture was heated to $50{ }^{\circ} \mathrm{C}$ for $2 \mathrm{~min}$ and then denatured at $95{ }^{\circ} \mathrm{C}$ for $10 \mathrm{~min}$. The amplification profile was as follows: 40 cycles of $95{ }^{\circ} \mathrm{C}$ for $15 \mathrm{~s}$ and then $60{ }^{\circ} \mathrm{C}$ for $1 \mathrm{~min}$. Reactions were performed in the ABI PRISM 7900HT Sequence Detection system and data analysed using the SDS 2.2 software (Applied Biosystems). $\Delta \Delta \mathrm{C}_{\mathrm{T}}$ was calculated as the $\mathrm{C}_{\mathrm{T}}$ value from the unstressed control cells minus the $\mathrm{C}_{\mathrm{T}}$ value from the stressed cells and corrected for differences in signals from the $16 \mathrm{~S}$ or gyrB controls.
Data acquisition and analysis. Slides were scanned with the ScanArray Express 1.0 scanner (Packard BioScience), following the manufacturer's guidelines. The intensities of the fluorescent spots were quantified with ImaGene 5 software (Biodiscovery). Background subtraction and normalization were performed in GeneSpring 6.1 (Silicon Genetics). All genes were spotted in triplicate on the slides to increase the accuracy of the measured intensities.

The data were evaluated statistically according to a recently developed approach (Langsrud, 2005) for analysing experiments designed with multiple responses and the calculations were made using the Matlab program at www.matforsk.no/ola/program.htm.

To detect significant differences, all four time points need to be modelled simultaneously. Our analysis was based on the second-order model:

$\log ($ ratio $)=A+B_{i}+C \cdot \log ($ time $)+D \cdot(\log (\text { time }))^{2}$

where $B_{i}(i=1,2,3)$ represents a block effect of biological replicates. The time $(\mathrm{min})$ is log-transformed to make the trends with time 
closer to linear. The second-order term is included to take into account possible deviations from linearity. If there is no effect of acid shock, all parameters in the above model are zero.

The constant term, A, represents the mean difference between the control and the four time points. An ordinary significance test of A would, however, give misleading results. The reason is that we have a common (not replicated) control at the four time points and therefore the SD of $\mathrm{A}$ is underestimated. It can be shown that a conservative estimate can be obtained by scaling the SD by a factor of $\sqrt{5}$. We applied this property to perform significance testing of $\mathrm{A}$ in a conservative way. The significance tests of $\mathrm{C}$ (linear trend) and D (deviation from linearity) were conducted as usual.

However, with several multiple responses, ordinary significance testing leads to a large number of falsely significant results (5\% of the total number of genes). Therefore, to draw reliable significance conclusions, the $P$ value of each gene was adjusted using a newly developed rotation-testing procedure; see Appendix in Moen et al. (2005). This method combines general linear modelling with $P$ value adjustments according to false-discovery rates (FDRs). When using adjusted $P$ values according to the FDR, one accepts that $5 \%$ of the genes reported as significantly differentially expressed at the $5 \%$ level are false results ( 31 of 622 genes). Compared to other FDR variants, an advantage of the rotation-testing method is that any kind of dependence between the genes is allowed.

\section{RESULTS AND DISCUSSION}

\section{DNA microarray measurements and statistics}

Growth of $S$. aureus after addition of $\mathrm{HCl}$ to $\mathrm{pH}=4.5$ is shown in Fig. 1. Control samples for microarray analyses were withdrawn immediately prior to the acid shock that lowered $\mathrm{pH}$ of the culture to 4.5 , and this was defined as

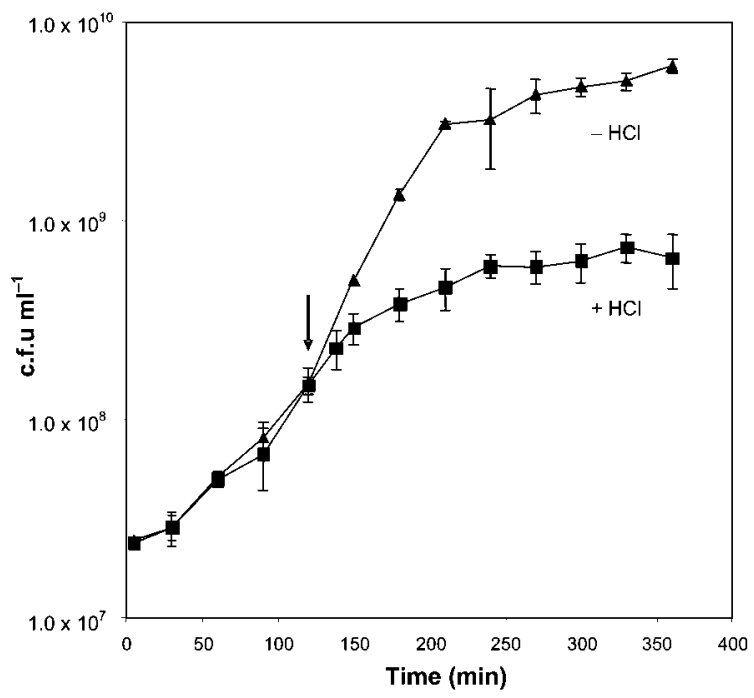

Fig. 1. Growth of $S$. aureus after addition of $\mathrm{HCl}$ to $\mathrm{pH}=4.5$. Cells were grown to $\mathrm{OD}_{600}=1.0$ before addition of acid (indicated by the arrow). Samples were then withdrawn and plated on TSA agar. $\boldsymbol{\square}$, Acidified cells; $\boldsymbol{\Lambda}$, control without acid addition. The results are the means of four experiments; error bars represent SD. time zero. The other samples for microarray analysis were withdrawn 2, 5, 10 and 20 min after the acid shock. In the microarray analyses, a total of 622 genes showed a statistically significant (at $5 \%$ FDR) change in expression level over the four time intervals measured. This result was due to significant mean differences and/or significant linear trends (log scale). No log ratios of gene expression showed significant deviation from linearity in the statistical model. Of the significant gene responses, 311 genes were upregulated and 311 genes down-regulated (Table 3). In general, most of the changes occurred within the first $10 \mathrm{~min}$, and for most of the responses the expression levelled out between 10 and 20 min after the acid shock (Fig. 2). The acid shock reduced the growth rate of the culture and the genetic expression profiles showed this clearly through the down-regulation of the biosynthesis of many macromolecules (Table 3, and see below). Of the genes showing a statistically significant change in expression, $59.6 \%$ showed a maximum change of expression larger than twofold, $23.3 \%$ were larger than threefold, $10.5 \%$ were larger than fourfold and $5.6 \%$ were larger than fivefold. Relatively few genes showed an aberrant pattern, a very fast upregulation or a very fast down-regulation, and none of these is commonly reported to be involved in acid-stress responses. We cannot address all responses in this paper, but an outline of the major responses observed is given. It is important to bear in mind that one cannot expect to see full correlation between gene expression levels and the corresponding activity of the gene product. Likewise, genes showing the highest fold-change might not coincide with the most important genetic response. Generally, one might expect an accumulation of many of the proteins for which gene expression was unchanged in the cell after acid shock, since growth was significantly reduced. No experiments to

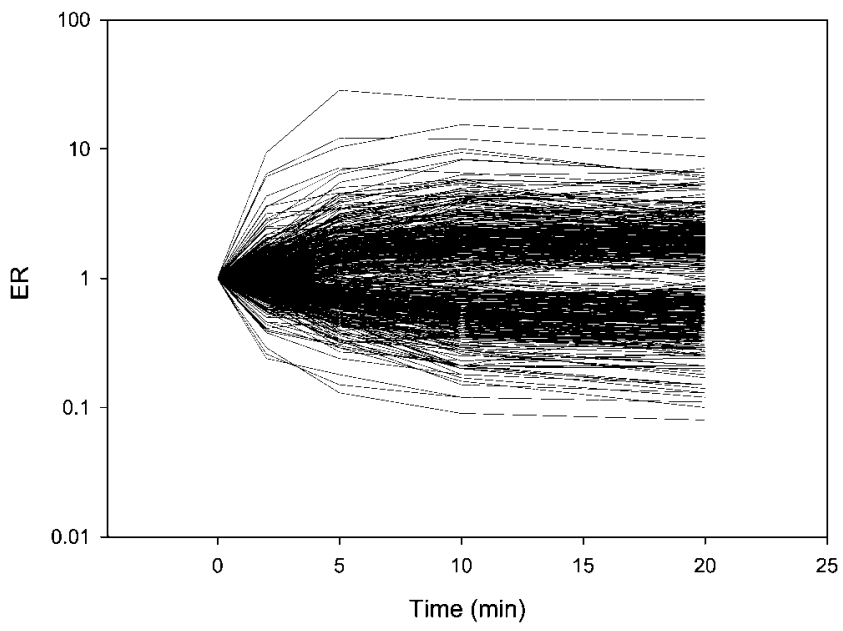

Fig. 2. Expression ratio (ER) profile for genes that showed statistically significant changes after acid-shocking. The scale is semi-logarithmic. $E R=1$ refers to the level of expression of the control, while $\mathrm{ER}=2$ and $\mathrm{ER}=0.5$ represent an increase or decrease, respectively, in expression by a factor of two. 
determine the extent to which this occurred were carried out, however. The literature on stress mechanisms in $S$. aureus is relatively sparse. Our results (Table 3 ) closely resembled responses described in the literature on acid stress in S. aureus or other bacteria. We also observed a number of additional responses.

Array data are often reported to underestimate the foldchange. To test the validity of the microarray data, cells were grown to $\mathrm{OD}_{600}=1$ before acid was added. After $10 \mathrm{~min}$ acid stress, cells were harvested. We then carried out QRT-PCR analysis on nine genes reacting to the acid stress with a range of fold-changes using $16 \mathrm{~S}$ and $\operatorname{gyrB}$ expression as the reference genes (Table 2). The two reference genes gave similar results. The QRT-PCR analysis agreed well with the microarray data and provided independent verification of changes in the transcript levels of the genes that we discuss in this paper.

\section{Direct acid-defence systems}

Neutralizing components. The urease genes encoding urease subunits $\mathrm{A}, \mathrm{B}$ and $\mathrm{C}$ (ure $A$, ureB and ureC), and ureF encoding the urease accessory protein UreF, were all strongly upregulated to a maximum ratio of 3.6-5.6 (Table 3, section F3). This result was similar to other findings where $S$. aureus was grown at $\mathrm{pH} 5.5$ or the bacterium was exposed to $1 \mathrm{mM}$ peracetic acid (Weinrick et al., 2004; Chang et al., 2006, respectively). Urease is a multimeric, nickel-containing enzyme that consists of six
UreA and six UreB subunits. Urease activity is known to be the major acid-resistance mechanism in Helicobacter pylori, which has adapted itself to live in the strongly acidic environment of the human stomach. In H. pylori, urease is expressed at very high levels, and the main role of the enzyme is thought to be neutralization of acidic microenvironments by production of $\mathrm{NH}_{3}$ and $\mathrm{CO}_{2}$. The $\mathrm{NH}_{3}$ produced can act as a buffer leaving the bacterial cytoplasm and entering the bacterial periplasm, by the formation of $\mathrm{NH}_{4}{ }^{+}$(Valenzuela et al., 2003). Urease is expressed by a wide variety of bacteria, although not at the high levels seen in $H$. pylori. In other bacteria, the urease activity is regulated in response to environmental changes such as changes in $\mathrm{pH}$, urea and nitrogen availability, and growth phase (Burne \& Chen, 2000; Chen et al., 1998). In being a nickel metalloenzyme, urease requires active uptake of nickel ions from the environment to maintain its activity. The nixA gene, encoding a nickel transporter necessary for full urease activity (Bauerfeind et al., 1996; Davis \& Mobley, 2005; Mobley et al., 1995; van Vliet et al., 2001), was found to be upregulated in our study at a similar level of expression as the urease genes (maximum 5.8-fold after $10 \mathrm{~min}$ ). Enhanced urease activity therefore seemed to be an important acid-shock mechanism for S. aureus 50583 to counteract the acidic environment.

The arginine deiminase (ADI) pathway generates alkaline compounds to help raise the cellular $\mathrm{pH}$ as a response to acid shock in many bacteria (Cotter \& Hill, 2003). Of the three main enzymes in the ADI pathway, only $\operatorname{arcC2}$

Table 2. QRT-PCR expression studies

\begin{tabular}{|c|c|c|c|c|c|c|c|c|c|}
\hline \multirow{2}{*}{$\begin{array}{l}\text { TIGR } \\
\text { locus }\end{array}$} & \multirow{2}{*}{ Gene } & \multirow[t]{2}{*}{ Gene function } & \multirow[t]{2}{*}{ Category $^{\star}$} & \multirow[t]{2}{*}{$\Delta \Delta \mathrm{C}_{\mathrm{T}}^{\dagger}(\mathbf{1 6 S})$} & \multirow{2}{*}{$\begin{array}{c}\text { Fold-change } \\
\text { (16S) PCR, } \\
10 \mathrm{~min}\end{array}$} & \multirow{2}{*}{$\begin{array}{c}\Delta \Delta \mathrm{C}_{\mathrm{T}} \neq \\
(g y r B)\end{array}$} & \multirow{2}{*}{$\begin{array}{c}\text { Fold-change } \\
(\text { gyrB) PCR, } \\
10 \mathrm{~min}\end{array}$} & \multicolumn{2}{|c|}{ Fold-change $\S$} \\
\hline & & & & & & & & $\begin{array}{l}\text { Arrays, } \\
10 \mathrm{~min}\end{array}$ & $\begin{array}{l}\text { Arrays, } \\
20 \mathrm{~min}\end{array}$ \\
\hline SA2280 & ureA & Urease, gamma subunit & $\begin{array}{l}\text { Central intermediary } \\
\text { metabolism }\end{array}$ & $5.57 \pm 0.97$ & 47.34 & $4.90 \pm 0.33$ & 29.75 & 2.76 & 3.59 \\
\hline SA2282 & ureC & Urease, alpha subunit & $\begin{array}{l}\text { Central intermediary } \\
\text { metabolism }\end{array}$ & $4.67 \pm 0.83$ & 25.37 & $4.00 \pm 1.46$ & 15.94 & 3.89 & 5.60 \\
\hline SA2654 & $\operatorname{arcC2}$ & Carbamate kinase & Energy metabolism & $-0.37 \pm 0.13$ & 0.77 & $-1.04 \pm 0.76$ & 0.49 & 0.64 & 0.61 \\
\hline SA0494 & nuoF & $\begin{array}{l}\text { NADH dehydrogenase, } \\
\text { putative }\end{array}$ & Energy metabolism & $2.66 \pm 0.11$ & 6.30 & $1.99 \pm 0.74$ & 3.96 & 4.76 & 3.81 \\
\hline SA2097 & $\operatorname{atp} A$ & $\begin{array}{l}\text { ATP synthase } F_{1} \\
\alpha \text { subunit }\end{array}$ & $\begin{array}{l}\text { ATP-proton motive } \\
\text { force interconversion }\end{array}$ & $-1.01 \pm 0.37$ & 0.50 & $-1.68 \pm 1.01$ & 0.31 & 0.51 & 0.44 \\
\hline SA1368 & katA & Catalase & Detoxification & $1.86 \pm 0.60$ & 3.62 & $1.19 \pm 0.04$ & 2.27 & 4.53 & 3.17 \\
\hline
\end{tabular}

${ }^{\star}$ According to TIGR database.

$\dagger \Delta \Delta \mathrm{C}_{\mathrm{T}}$ values are shown with SDs. 16S rRNA expression was used as reference.

$\ddagger \Delta \Delta \mathrm{C}_{\mathrm{T}}$ values are shown with sDs. gyrB expression was used as reference.

§Data extracted from Table 3. 
Table 3. Genes up- and down-regulated in S. aureus after acid-shocking

The table includes only genes commented on in the text; a more complete version is available as Supplementary Table S1. Statistically significant changes in expression are given as ratio of sample versus control (fold-change) for samples withdrawn 2, 5, 10 and $20 \mathrm{~min}$ after pH 4.5 acid shock. The data are grouped according to the categories given by the TIGR database (www.tigr.org). Major groups are numbered A1, A2, B1, etc. Highest and lowest ratios for each time curve are given in bold type.

\begin{tabular}{|c|c|c|c|c|c|c|c|}
\hline \multirow[t]{2}{*}{ Group } & \multirow[t]{2}{*}{ Locus } & \multirow[t]{2}{*}{ Gene } & \multirow[t]{2}{*}{ Common name } & \multicolumn{4}{|c|}{ Ratio } \\
\hline & & & & $2 \mathrm{~min}$ & $5 \mathrm{~min}$ & $10 \mathrm{~min}$ & $20 \mathrm{~min}$ \\
\hline \multicolumn{8}{|l|}{$\begin{array}{l}\text { A, purines, pyrimidines, } \\
\text { nucleosides and nucleotides }\end{array}$} \\
\hline \multirow{14}{*}{$\begin{array}{l}\text { A1, purine ribonucleotide } \\
\text { biosynthesis down-regulated }\end{array}$} & SA0018 & purA & Adenylosuccinate synthase & 0.77 & 0.59 & 0.46 & 0.42 \\
\hline & SA0544 & prsA & Ribose-phosphate pyrophosphokinase & 0.86 & 0.74 & 0.67 & 0.69 \\
\hline & SA1073 & purE & $\begin{array}{l}\text { Phosphoribosylaminoimidazole carboxylase, } \\
\text { catalytic subunit }\end{array}$ & 0.56 & 0.27 & 0.23 & 0.24 \\
\hline & SA1074 & purK & $\begin{array}{l}\text { Phosphoribosylaminoimidazole carboxylase, } \\
\text { ATPase subunit }\end{array}$ & 0.68 & 0.29 & 0.21 & 0.21 \\
\hline & SA1075 & purC & $\begin{array}{l}\text { Phosphoribosylaminoimidazole-succinocarboxamide } \\
\text { synthase }\end{array}$ & 0.77 & 0.37 & 0.25 & 0.24 \\
\hline & SA1076 & purS & Conserved hypothetical protein TIGR00302 & 0.88 & 0.47 & 0.23 & 0.26 \\
\hline & SA1077 & purQ & Phosphoribosylformylglycinamidine synthetase I & 0.96 & 0.44 & 0.27 & 0.25 \\
\hline & SA1078 & purL & Phosphoribosylformylglycinamidine synthase II & 1.05 & 0.61 & 0.39 & 0.31 \\
\hline & SA1079 & purF & Amidophosphoribosyltransferase & $1.39^{*}$ & 0.82 & 0.45 & $0.35^{\star}$ \\
\hline & SA 1080 & purM & Phosphoribosylformylglycinamidine cyclo-ligase & 1.45 & 1.03 & 0.67 & 0.40 \\
\hline & SA1081 & purN & Phosphoribosylglycinamide formyltransferase & 1.28 & 0.92 & 0.37 & 0.33 \\
\hline & SA1082 & purH & $\begin{array}{l}\text { Phosphoribosylaminoimidazolecarboxamide } \\
\text { formyltransferase/IMP cyclohydrolase }\end{array}$ & 1.38 & 1.03 & 0.72 & 0.46 \\
\hline & SA1083 & purD & Phosphoribosylamine-glycine ligase & 1.18 & 1.45 & 0.86 & 0.44 \\
\hline & SA1969 & purB & Adenylosuccinate lyase & 0.65 & 0.54 & 0.41 & 0.42 \\
\hline \multirow{7}{*}{$\begin{array}{l}\text { A2, pyrimidine ribonucleotide } \\
\text { biosynthesis down-regulated }\end{array}$} & SA1212 & pyrB & Aspartate carbamoyltransferase & 0.55 & 0.53 & 0.28 & 0.29 \\
\hline & SA1214 & carA & Carbamoyl-phosphate synthase, small subunit & 0.58 & 0.33 & 0.28 & 0.21 \\
\hline & SA1215 & $\operatorname{car} B$ & Carbamoyl-phosphate synthase, large subunit & 0.62 & 0.38 & 0.28 & 0.17 \\
\hline & SA1216 & pyrF & Orotidine $5^{\prime}$-phosphate decarboxylase & 0.55 & 0.36 & 0.20 & 0.15 \\
\hline & SA1217 & pyrE & Orotate phosphoribosyltransferase & 0.76 & 0.53 & 0.30 & 0.26 \\
\hline & SA2119 & pyrG & CTP synthase & 0.58 & 0.52 & 0.39 & 0.31 \\
\hline & SA2606 & pyrD & Dihydroorotate dehydrogenase & 0.39 & 0.30 & 0.21 & 0.27 \\
\hline \multirow{7}{*}{$\begin{array}{l}\text { A3, nucleotide and nucleoside } \\
\text { interconversions } \\
\text { down-regulated }\end{array}$} & SA0603 & & Deoxynucleoside kinase family protein & 0.83 & 0.69 & 0.59 & 0.66 \\
\hline & SA0604 & & Deoxynucleoside kinase family protein & 1.01 & 0.63 & 0.58 & 0.65 \\
\hline & SA1277 & pyrH & Uridylate kinase & 0.85 & 0.71 & 0.60 & 0.61 \\
\hline & SA1371 & $g u a C$ & GMP reductase & 0.95 & 0.70 & 0.47 & 0.32 \\
\hline & SA1509 & & Nucleoside diphosphate kinase & 0.93 & 0.70 & 0.71 & 0.83 \\
\hline & SA2111 & $t d k$ & Thymidine kinase & 0.62 & 0.47 & 0.35 & 0.44 \\
\hline & SA2218 & $a d k$ & Adenylate kinase & 1.12 & 0.83 & 0.63 & 0.44 \\
\hline \multirow{7}{*}{$\begin{array}{l}\text { A6, DNA metabolism: DNA } \\
\text { replication, recombination } \\
\text { and repair upregulated }\end{array}$} & SA0970 & $\operatorname{rex} B$ & Exonuclease RexB & 1.28 & 1.86 & 2.24 & 1.70 \\
\hline & SA0971 & $\operatorname{rexA}$ & Exonuclease RexA & 1.02 & 1.26 & 2.27 & 1.95 \\
\hline & SA1157 & uvrC & Excinuclease ABC, $C$ subunit & 1.06 & 1.35 & 1.94 & 2.01 \\
\hline & SA1224 & priA & Primosomal protein $\mathrm{N}^{\prime}$ & 1.16 & 1.49 & 1.97 & 1.46 \\
\hline & SA1492 & nth & Endonuclease III & 1.30 & 1.98 & 1.81 & 1.19 \\
\hline & SA1737 & polA & DNA polymerase I & 1.17 & 1.38 & 1.87 & 1.54 \\
\hline & SA1955 & $\operatorname{din} P$ & DNA-damage-inducible protein $\mathrm{P}$ & 2.16 & 3.91 & 3.63 & 2.86 \\
\hline Down-regulated & SA1381 & $s b c D$ & Exonuclease SbcD & 0.95 & 0.86 & 0.72 & 0.64 \\
\hline \multicolumn{8}{|l|}{$\mathrm{B}$, transporters } \\
\hline \multirow{3}{*}{$\begin{array}{l}\text { B2, transport and binding } \\
\text { proteins: }(\text { anions })^{2} \text {, cations } \\
\text { and iron-carrying } \\
\text { compounds upregulated }\end{array}$} & SA0687 & & $\mathrm{Na}^{+} / \mathrm{H}^{+}$antiporter & 1.23 & 1.39 & 2.34 & 2.67 \\
\hline & SA2572 & & Copper-translocating P-type ATPase & 1.62 & 2.15 & 3.16 & 2.38 \\
\hline & SA2721 & nixA & High-affinity nickel transporter & 1.72 & 3.43 & 5.82 & 5.14 \\
\hline
\end{tabular}


Table 3. cont.

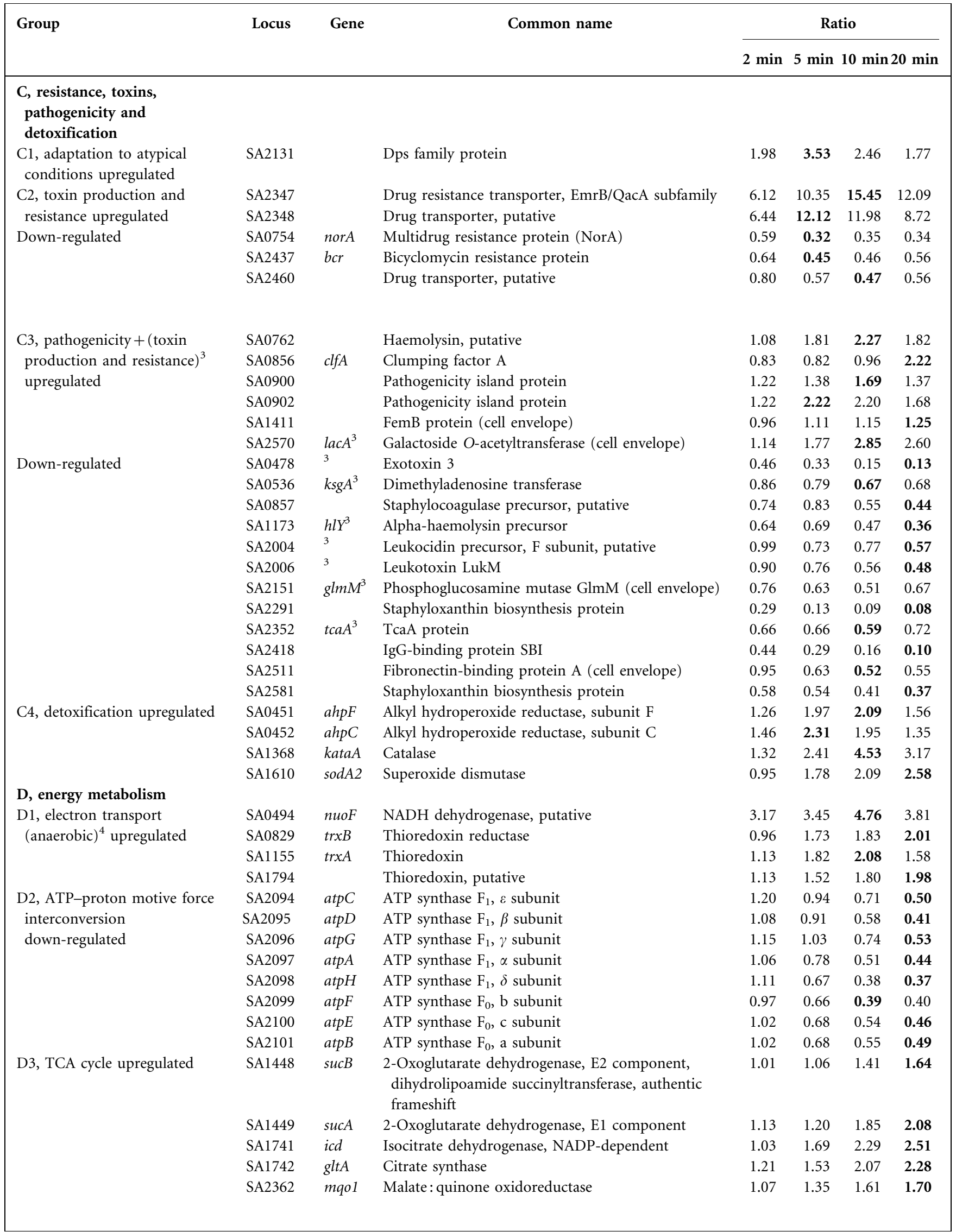


Table 3. cont.

\begin{tabular}{|c|c|c|c|c|c|c|c|}
\hline \multirow[t]{2}{*}{ Group } & \multirow[t]{2}{*}{ Locus } & \multirow[t]{2}{*}{ Gene } & \multirow[t]{2}{*}{ Common name } & \multicolumn{4}{|c|}{ Ratio } \\
\hline & & & & $2 \mathrm{~min}$ & $5 \mathrm{~min}$ & $10 \min 2$ & $20 \mathrm{~min}$ \\
\hline \multirow{4}{*}{$\begin{array}{l}\text { D4, glycolysis/gluconeogenesis } \\
\text { upregulated }\end{array}$} & SA0842 & eno & Enolase & 1.13 & 1.14 & 1.42 & 1.66 \\
\hline & SA0966 & $p g i$ & Glucose-6-phosphate isomerase & 0.75 & 1.26 & 1.25 & 1.67 \\
\hline & SA2415 & $g p m$ & Phosphoglycerate mutase & 9.37 & 28.53 & 24.11 & 24.06 \\
\hline & SA2622 & $f d a B$ & Fructose-diphosphate aldolase, class I & 1.20 & 2.83 & 4.09 & 7.10 \\
\hline \multirow[t]{3}{*}{ D5, PPP upregulated } & SA1377 & $t k t$ & Transketolase & 1.31 & 1.31 & 1.79 & 2.11 \\
\hline & SA1549 & $z w f$ & Glucose-6-phosphate 1-dehydrogenase & 1.50 & 2.34 & 3.12 & 2.58 \\
\hline & SA1554 & gnd & 6-Phosphogluconate dehydrogenase, decarboxylating & 1.04 & 1.58 & 2.09 & 1.55 \\
\hline \multirow[t]{4}{*}{ D7, fermentation upregulated } & SA0154 & $\operatorname{ald} A 1$ & Aldehyde dehydrogenase & 0.76 & 1.07 & 1.38 & 1.76 \\
\hline & SA1984 & aldA2 & Aldehyde dehydrogenase & 0.84 & 0.84 & 1.33 & 1.56 \\
\hline & SA2198 & $\begin{array}{l}\text { aldCl } \\
\text { budA1 }\end{array}$ & Alpha-acetolactate decarboxylase, putative & 1.75 & 4.51 & 5.73 & 5.30 \\
\hline & SA2199 & $b u d B$ & Acetolactate synthase, catabolic & 2.52 & 4.45 & 4.26 & 4.82 \\
\hline $\begin{array}{l}\text { D8, amino acids and } \\
\text { amines }+(\text { other energy } \\
\text { metabolism })^{6} \text { upregulated }\end{array}$ & SA2624 & 6 & Acetyl-CoA synthetase, putative & 1.68 & 2.95 & 4.06 & 4.22 \\
\hline Down-regulated & SA2654 & $\operatorname{arcC2}$ & Carbamate kinase & 0.80 & 0.69 & 0.64 & 0.61 \\
\hline \multicolumn{8}{|l|}{ E, protein synthesis } \\
\hline \multirow{2}{*}{$\begin{array}{l}\text { E3, protein synthesis } \\
\text { (translation factors, tRNA } \\
\text { and rRNA base modification, } \\
\text { tRNA aminoacylation) } \\
\text { upregulated }\end{array}$} & SA0576 & cyss & Cysteinyl-tRNA synthetase & 1.20 & 1.31 & 1.34 & $\begin{array}{l}1.71 \\
2.23\end{array}$ \\
\hline & SA1808 & leus & Leucyl-tRNA synthetase & 1.27 & 1.74 & 2.08 & 2.23 \\
\hline \multirow[t]{5}{*}{ Down-regulated } & SA0562 & lys $S$ & Lysyl-tRNA synthetase & 0.98 & 0.82 & 0.80 & 0.73 \\
\hline & SA0574 & glt $X$ & Glutamyl-tRNA synthetase & 0.88 & 0.70 & 0.55 & 0.58 \\
\hline & SA0663 & $\arg S$ & Arginyl-tRNA synthetase & 0.92 & 0.82 & 0.67 & 0.64 \\
\hline & SA1148 & phes & Phenylalanyl-tRNA synthetase, alpha subunit & 1.01 & 0.75 & 0.72 & 0.82 \\
\hline & SA1778 & $\operatorname{tyr} S$ & Tyrosyl-tRNA synthetase & 0.80 & 0.73 & 0.57 & 0.73 \\
\hline \multirow{12}{*}{$\begin{array}{l}\text { E5, protein fate: degradation } \\
\text { of proteins, peptides, and } \\
\text { glycopeptides upregulated }\end{array}$} & SA0085 & & Peptidase, M20/M25/M40 family & 3.61 & 4.58 & 4.01 & 2.36 \\
\hline & SA0570 & $c l p C$ & $\begin{array}{l}\text { ATP-dependent Clp protease, ATP-binding } \\
\text { subunit ClpC, authentic frameshift }\end{array}$ & 1.04 & 1.81 & 3.57 & 2.46 \\
\hline & SA0595 & & Peptidase, M20/M25/M40 family & 1.23 & 2.07 & 2.69 & 2.41 \\
\hline & SA0979 & $\operatorname{clp} B$ & $\begin{array}{l}\text { ATP-dependent Clp protease, ATP-binding } \\
\text { subunit ClpB }\end{array}$ & 1.53 & 4.34 & 8.23 & 6.56 \\
\hline & SA1555 & & Peptidase, M20/M25/M40 family & 1.60 & 3.10 & 4.36 & 3.77 \\
\hline & SA1588 & & Proline dipeptidase & 0.90 & 1.50 & 1.62 & 1.61 \\
\hline & SA1756 & pepQ & Proline dipeptidase & 1.00 & 1.43 & 1.73 & 2.22 \\
\hline & SA1777 & & Serine protease HtrA & 0.86 & 1.13 & 1.27 & 1.50 \\
\hline & SA1795 & рерA1 & Glutamyl aminopeptidase & 1.19 & 1.53 & 2.03 & 1.93 \\
\hline & SA2007 & & $\begin{array}{l}\text { Peptidase, M20/M25/M40 family, authentic } \\
\text { frameshift }\end{array}$ & 0.91 & 1.15 & 1.52 & 2.39 \\
\hline & SA2463 & рерА2 & Glutamyl aminopeptidase & 1.29 & 2.49 & 3.35 & 3.28 \\
\hline & SA2563 & & ATP-dependent Clp protease, putative & 0.95 & 0.80 & 1.28 & 3.33 \\
\hline \multicolumn{8}{|l|}{ F, metabolism } \\
\hline \multirow{4}{*}{$\begin{array}{l}\text { F3, central intermediary } \\
\text { metabolism; }(\text { amino sugars })^{8}, \\
(\text { nitrogen })^{9},(\text { sulfur })^{10} \\
(\text { one-carbon })^{11}, \text { other } \\
\text { upregulated }\end{array}$} & SA2280 & ure $A^{9}$ & Urease, gamma subunit & 1.18 & 1.58 & 2.76 & 3.59 \\
\hline & SA2281 & ure $B^{9}$ & Urease, beta subunit & 1.51 & 2.14 & 2.84 & 5.39 \\
\hline & SA2282 & ure $C^{9}$ & Urease, alpha subunit & 1.51 & 2.47 & 3.89 & 5.60 \\
\hline & SA2284 & ureF $F^{9}$ & Urease accessory protein UreF & 1.17 & 1.87 & 2.66 & 4.48 \\
\hline \multicolumn{8}{|l|}{$\mathrm{G}$, regulatory functions } \\
\hline $\begin{array}{l}\text { G1, two-component system }+ \\
\text { protein interactions }+\end{array}$ & SA1740 & pho $P^{13}$ & $\begin{array}{l}\text { Alkaline phosphatase synthesis transcriptional } \\
\text { regulatory protein PhoP }\end{array}$ & 1.32 & 1.69 & 1.88 & 1.85 \\
\hline$(\text { pathogenicity })^{12},($ DNA & SA1943 & $\operatorname{vraS}^{14}$ & Sensor histidine kinase & 0.88 & 1.14 & 1.62 & 1.57 \\
\hline $\begin{array}{l}\text { interactions })^{13},(\text { toxin } \\
\text { production and resistance })^{14} \\
\text { upregulated }\end{array}$ & SA2070 & $k d p D$ & Sensor histidine kinase & 1.25 & 1.75 & 2.51 & 2.49 \\
\hline
\end{tabular}


Table 3. cont.

\begin{tabular}{|c|c|c|c|c|c|c|c|}
\hline \multirow[t]{2}{*}{ Group } & \multirow[t]{2}{*}{ Locus } & \multirow[t]{2}{*}{ Gene } & \multirow[t]{2}{*}{ Common name } & \multicolumn{4}{|c|}{ Ratio } \\
\hline & & & & $2 \mathrm{~min}$ & $5 \mathrm{~min}$ & $10 \min$ & $20 \mathrm{~min}$ \\
\hline \multirow[t]{2}{*}{ Down-regulated } & SA0765 & $s a e S^{12}$ & Sensor histidine kinase SaeS & 1.06 & 0.86 & 0.66 & 0.48 \\
\hline & SA0766 & $s a e R^{12}$ & Two-component signal transduction protein SaeR & 0.89 & 0.60 & 0.39 & 0.35 \\
\hline $\begin{array}{l}\text { G2, protein interactions } \\
\text { down-regulated }\end{array}$ & SA2057 & $r s b U$ & $\sigma^{\mathrm{B}}$ regulator protein & 0.98 & 0.83 & 0.80 & 0.73 \\
\hline $\begin{array}{l}\text { G3, RNA interactions } \\
\text { down-regulated }\end{array}$ & SA 1210 & pyrR & Pyrimidine operon regulatory protein & 0.41 & 0.47 & 0.20 & 0.21 \\
\hline \multirow{4}{*}{$\begin{array}{l}\text { G4, DNA interactions } \\
\text { upregulated }\end{array}$} & SA0567 & ctsR & Transcriptional regulator CtsR & 1.55 & 3.14 & 3.42 & 2.31 \\
\hline & SA1541 & & Transcriptional regulator, Fur family & 1.71 & 2.11 & 1.92 & 0.98 \\
\hline & SA2193 & & Transcriptional regulator, MerR family & 1.62 & 1.72 & 2.38 & 1.96 \\
\hline & SA2517 & & Transcriptional regulator, MerR family & 1.03 & 1.38 & 1.91 & 2.32 \\
\hline \multicolumn{8}{|l|}{$\mathrm{H}$, cell envelope } \\
\hline $\mathrm{H} 1$, biosynthesis and & SA2689 & $i c a A$ & IcaA protein; intercellular adhesion protein A & 0.83 & 0.38 & 0.21 & 0.15 \\
\hline degradation of surface & SA2690 & $i c a D$ & IcaD protein; intercellular adhesion protein $\mathrm{D}$ & 0.96 & 0.40 & 0.20 & 0.13 \\
\hline polysaccharides and & SA2691 & $i c a B$ & IcaB protein; intercellular adhesion protein $\mathrm{B}$ & 0.86 & 0.34 & 0.17 & 0.12 \\
\hline $\begin{array}{l}\text { lipopolysaccharides } \\
\text { down-regulated }\end{array}$ & SA2692 & $i c a C$ & $\begin{array}{l}\text { IcaC protein; intercellular adhesion protein } \mathrm{D} \text {; } \\
\text { authentic frameshift }\end{array}$ & 0.92 & 0.45 & 0.21 & 0.14 \\
\hline $\begin{array}{l}\text { H3, other (cell envelope) } \\
\text { down-regulated }\end{array}$ & SA2509 & $f n b B$ & Fibronectin-binding protein $\mathrm{B}$ & 0.94 & 0.65 & 0.47 & 0.34 \\
\hline
\end{tabular}

${ }^{*}$ When there was a clear upregulation at one time point and a clear down-regulation at an earlier or later time point, both values are given in bold type.

${ }^{2-14}$ Footnote numbers refer to subgroups of genes in groups for which the heading includes several types of gene. A full set of footnotes is given in Supplementary Table S1.

encoding carbamate kinase showed any significant change in our data, and this gene was down-regulated (minimum 0.61 ), suggesting that the ADI pathway is not a major acidshock response in the $S$. aureus 50583 strain under the conditions given. A similar down-regulation of $\operatorname{arcC} 2$ has been observed in peracetic acid-treated cells (Chang et al., 2006).

Proton efflux. The gene nuoF encoding an NADH dehydrogenase was found to be upregulated (maximum ratio of 4.76 after $10 \mathrm{~min}$ ). This dehydrogenase moves $2 \mathrm{H}^{+}$ across the membrane and out of the cell, converting one $\mathrm{NADH}$ to $\mathrm{NAD}^{+}$, and thereby helps to increase the internal $\mathrm{pH}$ of the cell. Somewhat surprisingly, we found that the $\mathrm{F}_{0} \mathrm{~F}_{1}$ ATPase was down-regulated at $\mathrm{pH}$ 4.5. All genes encoding subunits for both $\mathrm{F}_{1}(\alpha, \beta, \gamma, \delta$ and $\varepsilon)$ and $\mathrm{F}_{0}(\mathrm{a}, \mathrm{b}$ and $\mathrm{c}$ ) were down-regulated to minimum ratios of the order of $0.37-0.53$ (Table 3 , section D2). In the literature, $\mathrm{F}_{0} \mathrm{~F}_{1}$ ATPases are often mentioned as one of the primary mechanisms for extruding protons in many Grampositive bacteria (Foster, 2004). Len et al. (2004) have shown increased levels of $\mathrm{F}_{0} \mathrm{~F}_{1}$ ATPase at $\mathrm{pH} 5.0$ in Streptococcus mutans. On the other hand, microarray analysis of $S$. aureus does not show any significant change in expression of the $\mathrm{F}_{0} \mathrm{~F}_{1}$ ATPase genes when cells are grown at $\mathrm{pH} 5.5$ or subjected to $1 \mathrm{mM}$ peracetic acid (Weinrick et al., 2004; Chang et al., 2006). In addition, recent work by Maurer et al. (2005) has shown that in E. coli, the ATPase genes are induced at high $\mathrm{pH}$ rather than at low $\mathrm{pH}$. The genetic expression was clearly reduced to about $50 \%$, but the ATPase could still play an important role by pumping $\mathrm{H}^{+}$out of the cells, since regulation of ATPase activity apparently occurs at the assembly stage (Arikado et al., 1999). The gene SACOL0687, encoding a Na ${ }^{+} / \mathrm{H}^{+}$antiporter, was upregulated.

Reducing power. As the acid shock leads to increased consumption of reducing power in the form of NADPH and $\mathrm{NADH}$, an urgent need to generate more reducing power arises in bacterial cells. For NADPH, this need can be met by increased flow through the pentose phosphate pathway (PPP). Several genes encoding enzymes in the PPP and in the overlap between the PPP and glycolysis were upregulated after the acid shock ( $z w f$, gnd, $t k t, p g i, f d a B)$. None of these genes has been reported to show changes in expression when cells are grown at $\mathrm{pH} 5.5$ (Weinrick et al., 2004). The gene $z w f$, encoding the glucose-6-phosphate dehydrogenase, is the first irreversible enzyme leading into the PPP. Together with gnd (6-phosphogluconate dehydrogenase) it controls the carbon flow into the PPP. Both these genes were found to be upregulated in our study (zwf 3.1fold and gnd 2.1-fold after $10 \mathrm{~min}$ ). Upregulation of $z w f$ as a response to oxidative stress and recovery from heat stress has been demonstrated for Gram-negative bacteria (Cohen et al., 1993; Greenberg et al., 1990; Kobayashi et al., 2005; Ma et al., 1998). 
Several genes encoding enzymes in the tricarboxylic acid (TCA) cycle were also upregulated after the acid shock (sucA, sucB, icd, gltA, mqo1). The sucA and sucB genes in the TCA cycle encode 2-oxoglutarate dehydrogenase. It has been proposed that this complex may provide succinylCoA for phosphorylation of GDP and ADP under conditions of restricted $\mathrm{NAD}^{+}$availability, which could be essential upon accumulation of NADH and exhaustion of the pyridine nucleotide pool (Bunik, 2003).

Several genes involved in conversion of acetate to ethanol were upregulated after the acid shock. Among these were four zinc-containing alcohol dehydrogenases, two aldehyde dehydrogenases (AldA1, AldA2), and $\alpha$-acetolactate decarboxylase (BudA1) and acetolactate synthase (BudB). Increased activity of these dehydrogenases would accelerate the regeneration of $\mathrm{NAD}^{+}$, and one might also speculate that this could raise the intracellular $\mathrm{pH}$ by the removal of acetate. Len et al. (2004) have reported a 4.6-fold higher level of ethanol produced by Strep. mutans grown at $\mathrm{pH} 5.0$ compared with $\mathrm{pH}$ 7.0.

Among other energy-metabolism genes showing a significant increase in expression was an acetyl-CoA synthetase (SACOL2624), which could generate acetyl-CoA from acetate for use in the TCA cycle. The two genes bud A1 and $b u d B$ (maximum upregulation 5.7- and 4.8-fold, respectively) are also part of the $\mathrm{C}_{5}$-branched dibasic acid metabolism pathway and encode enzymes that produce acetoin. It is known that conversion of pyruvate to acetoin contributes to maintenance of $\mathrm{pH}$ homeostasis in Lactobacillus plantarum (Tsau et al., 1992).

Regulators. Several regulatory genes play a role in the exponential-phase acid-tolerance response. Among these, $r s b U$ was found to be down-regulated, while phoP and SACOL1541 (transcriptional regulator of the iron regulator Fur family) were found to be upregulated (Table 3, section G). Also, many other transcriptional regulators showed a significant change of expression in our data (Table 3, section $\mathrm{G})$. The $r s b U$ gene encodes the $\sigma^{\mathrm{B}}$ regulator RsbU, which is thought to be the major activator of the $\sigma^{\mathrm{B}}$ response to acid stress in S. aureus (Palma \& Cheung, 2001). The down-regulation of this gene is in agreement with the lack of any significant increase for $\sigma^{\mathrm{B}} . \sigma^{\mathrm{B}}$ partially controls another well-studied signal-transduction regulatory component, sarA (Deora et al., 1997; Manna et al., 1998; Miyazaki et al., 1999), the expression of which remained unchanged after the acid shock. In Salmonella enterica, $\sigma^{\mathrm{s}}$, PhoP and Fur are known to be induced by acid shock to $\mathrm{pH} 4.5$, and rpos, phoP and fur mutants are known to be acid sensitive (Foster, 2004). Besides phoP, two genes involved in different two-component systems were upregulated $(k d p D$ and $v r a S)$, while two were downregulated (saeS and saeR). The latter two genes are known to be important for virulence (Novick \& Jiang, 2003), while $\mathrm{KdpD}$ is involved in sensing $\mathrm{K}^{+}$levels (Epstein, 2003; Wood, 1999) and VraS is involved in the cell wall stimulon response (Kuroda et al., 2003).

\section{Indirect responses}

Oxidative stress response. The ability to defend against oxidative stress is of vital importance to $S$. aureus when attacked by host phagocytes at the site of bacterial infection. Oxidative-defence mechanisms are also generally important for bacterial survival in the environment, and the enzymes involved may provide the bacteria with a defence against oxidative threats such as the disinfectants employed in the food industry and in hospitals. Our results showed upregulation of the superoxide dismutase (SOD) gene sodA and the catalase gene katA, thus connecting the acid response to the oxidative-stress response. The SodA protein can reduce the rate of neutrophil-mediated killing and destroys highly reactive $\mathrm{O}_{2}^{-}$(Clements \& Foster, 1999). Adaptation of $S$. aureus to acid leads to induction of $\operatorname{sod} A$, and $\operatorname{sodA}$ mutants are known to be more sensitive to acid (Clements et al., 1999). KatA is the only major catalase in S. aureus and accumulates extracellularly, converting $\mathrm{H}_{2} \mathrm{O}_{2}$ to water. When cells are grown at $\mathrm{pH} 5.5$, no increase in katA and $\operatorname{sodA}$ expression has been reported (Weinrick et al., 2004). Somewhat surprisingly, this is also the case when cells are subjected to $1 \mathrm{mM}$ peracetic acid (Chang et al., 2006).

Our results also showed an upregulation of the genes $a h p C$ and $a h p F$ that encode the alkyl hydroperoxide reductase subunits $\mathrm{C}$ and $\mathrm{F}$, respectively. Alkyl hydroperoxide reductase $(\mathrm{AhpC})$ protects cells against $\mathrm{OONO}^{-}$, which is also generated within neutrophils and macrophages. The gene ahpC has been shown to be induced by osmotic stress but not by oxidative stress in $S$. aureus (Armstrong-Buisseret et al., 1995). Regulation of katA and ahpC via perR has been described previously (Horsburgh et al., 2001).

Three thioredoxin genes were shown to be upregulated in our data $(\operatorname{tr} x A, \operatorname{trx} B$ and SACOL1794). Thiol-specific redox systems are vital for the protection of cells against toxic oxygen species. They also play a major role in maintaining the intracellular thiol-disulfide balance and in providing reducing power to the key reductive enzymes, such as ribonucleotide reductases. In many prokaryotes, thioredoxin and glutaredoxin execute these tasks. S. aureus lacks glutathione and must therefore employ thioredoxin and alternative thioredoxin-based systems, such as alkyl hydroperoxide reductases, to carry out these cellular processes (Hofmann et al., 2002). Thioredoxins are small ubiquitous proteins participating in numerous dithiol-disulfide interchange reactions. One of the established functions of thioredoxins is to reduce disulfide bonds in target proteins. The reducing power for this is provided by thioredoxin reductase, which in turn is reduced by NADPH. Thioredoxin is also essential for growth (Uziel et al., 2004). Linkage between acid and oxidative responses has also been suggested by others, for both S. aureus and E. coli (Clements \& Foster, 1999; Clements et al., 1999; Maurer et al., 2005).

Metal transporters. In general, the expression of many genes that encode transporters was significantly changed after the acid shock, and that of $\mathrm{ABC}$ transporters in 
particular. The gene SACOL2572, encoding a coppertranslocating P-type ATPase, was upregulated. The coppertranslocating P-type ATPase can pump excess $\mathrm{Cu}^{2+}$ ions out of the cell at the expense of ATP. Low $\mathrm{pH}$ can increase metal ion toxicity in bacteria, and an excess of metal ions causes oxidative damage. The sensing and regulation of metal ion levels are therefore essential for the cell in a stressed situation. The merR regulators are known to be involved in the regulation of heavy metal ion concentrations in many bacteria (for a review see Brown et al., 2003), and two of these merR regulator genes (SACOL2193 and SACOL2517) were upregulated in the acid-shocked cells.

Genes encoding transporters of metal ions, such as nickel, iron and manganese, as well as genes encoding $\mathrm{ABC}$ transporter systems for the transport of molybdenum and zinc into cells, were upregulated after the acid shock (Table 3, sections B2 and B5). One might speculate that this is due to an increased need for these essential metal ions in enzyme systems (Kisker et al., 1997). As stated above, several zinccontaining alcohol dehydrogenase genes and the nixA gene encoding a nickel transporter were found to be upregulated. Likewise, eight genes involved in molybdopterin cofactor synthesis were upregulated. In the Gram-positive bacterium Streptomyces coelicolor, others have linked molybdopterin biosynthesis to disulphide stress caused by the thioredoxin activity (see above) which follows from oxidative stress (Paget et al., 2001).

Other transporters. Several genes encoding transporters of osmoprotectants were found to be upregulated. Downregulated transporter genes included those encoding transporters for formate and lactate, spermidine/putrescine, sugars and amino acids. The reduction in expression of transporters for spermidine and putrescine is interesting, since these are alkaline compounds that might contribute to keeping a higher $\mathrm{pH}$ inside the cell.

DNA-repair systems. It is well known that low pH causes damage to DNA. One would therefore expect expression changes in genes involved in DNA replication and repair.

DNA-damage-inducible protein $\mathrm{P}(\operatorname{din} P)$ showed an early increase in expression. Also, several genes involved in DNA replication and repair, such as polA, encoding DNA polymerase I, and rexA and rexB, encoding the exonucleases RexA and RexB, respectively, were found to be upregulated. In Gram-positive bacteria, the exonuclease/helicase RexAB is a major component of the homologous recombination process and is essential for double-strand DNA break repair (Chedin \& Kowalczykowski, 2002; Quiberoni et al., 2001). On the other hand, other genes involved in DNA repair and replication were found to be downregulated, e.g. DNA-repair protein RecN and exonuclease $\mathrm{SbcD}$. The gene priA, encoding a helicase (Lasken \& Kornberg, 1988), was found to be upregulated. Others have shown that inactivation of this gene induces the SOS response in E. coli (Nurse et al., 1991).
Changes related to metabolism and growth. The lower growth rate of the bacterium after the acid shock was reflected in the down-regulation of a high number of genes involved in protein synthesis, as well as in fatty acid and phospholipid metabolism. A total of 42 ribosomal protein genes showed significant down-regulation after the $\mathrm{pH}$ drop (Table 3, section E2). Only two were upregulated ( $r p m G$ and $r p s A$ ). In addition, frr, encoding ribosome recycling factor, was down-regulated. The level of downregulation was in the range $0.25-0.63$ with an average of 0.46 , with a general tendency for a gradual decrease from time zero to $20 \mathrm{~min}$. We also found several other genes involved in protein synthesis to be down-regulated, including translation factors, tRNA and rRNA base modification genes, and genes linked to tRNA aminoacylation. Among these, five tRNA synthetase genes (tyrS, pheS, argS, $g l t X$ and $l y s S$ ) were shown to be down-regulated, while cysteinyl- and leucyl-tRNA synthetases (CysS and LeuS) were upregulated.

Likewise, the lower growth rate resulted in down-regulation of seven and 14 genes, respectively, of the pyrimidine and purine ribonucleotide biosynthesis pathways (Table 3, sections A1-A2). The same was also the case for seven genes involved in nucleotide and nucleoside interconversions (Table 3, section A3). While most of the PPP was upregulated to generate reducing power, the gene prsA (ribose-phosphate pyrophosphokinase), catalysing the first step from D-ribose-5-phosphate from the PPP into the pyrimidine and purine synthesis pathways, was found to be down-regulated. Also the regulator gene $p y r R$, encoding pyrimidine operon regulatory protein, showed a major down-regulation in expression level after the acid shock.

In contrast to the major down-regulation of genes involved in protein and nucleotide synthesis, we found that a number of genes involved in the degradation of proteins, peptides and glycopeptides were upregulated at relatively high ratios (Table 3, section E5). Four genes involved in protein modification and repair were also upregulated. The upregulation of these types of genes could be a result of both an increased need for the degradation of proteins subjected to acid denaturation and inactivation, and a need for amino acids for the increased synthesis of proteins involved in the acid response. Three peptidases were also found to be down-regulated (M16 family and U32 family).

Our results indicated that both $\operatorname{clp} B$ and $\operatorname{clp} C$, encoding subunits of an ATP-dependent Clp protease, are part of an acid-shock response in $S$. aureus 50583, as we saw a major upregulation with maximum expression $10 \mathrm{~min}$ after the acid shock (8.2-fold for $c l p B$ and 3.6-fold for $c l p C$ ), followed by a slight decrease in expression from 10 to $20 \mathrm{~min}$. This decrease is consistent with the increase in expression of the $c t s R$ gene, encoding a negative heat-shock regulator known to control expression of $\operatorname{clp} B$ and $\operatorname{clp} C$ (Frees et al., 2004). Those authors have shown that $\mathrm{ClpC}$ is required for the repressor activity of CtsR, and suggest that 
$\mathrm{ClpC}$ is a stress sensor for S. aureus during environmental stress and infection (Frees et al., 2004). The gene SACOL2563, encoding a putative ATP-dependent Clp protease, was also found to be upregulated after the acid shock. Others have recently shown that $S$. aureus $\mathrm{ClpC}$ is required for resistance to stresses such as oxidative and heat stress, aconitase activity, growth recovery and death (Chatterjee et al., 2005; Frees et al., 2004), as well as biofilm formation and thermotolerance, in which $\mathrm{ClpB}$ also plays an important role (Frees et al., 2004). In Listeria monocytogenes, $\operatorname{clp} B$ has been linked to virulence and shown not to be involved in stress tolerance (Chastanet et al., 2004). Upregulation of $c l p B$ in $S$. aureus exposed to acid has also been reported by Weinrick et al. (2004) at steady state after 6 h growth. The gene SACOL1777, encoding HtrA serine protease, was also found to be upregulated. In E. coli, the HtrA protease is known to be heat-shock induced, and its main role is to degrade misfolded proteins in the periplasm (Pallen \& Wren, 1997).

Genes encoding enzymes in the major energy metabolic pathway, glycolysis, generally showed only minor changes in expression after the acid shock. The exception was the gene $f d a B$, encoding fructose-diphosphate aldolase, which showed an increase in expression of up to 7.1-fold after $20 \mathrm{~min}$. The genes pgi (glucose-6-phosphate isomerase) and eno (enolase) showed a small but statistically significant increase ( $\sim 1.6$-fold). Both glucose-6-phosphate isomerase and fructose-diphosphate aldolase are enzymes that are active in the junction between PPP and glycolysis, and this could explain the upregulation of the genes encoding these enzymes.

S. aureus contains several genes that encode phosphoglycerate mutase. One of these genes, gpm, was highly upregulated (28.5-fold). Phosphoglycerate mutase is one of the enzymes in the glycolysis pathway. Given the high level of upregulation of this gene, a codon adaptation index (CAI) analysis was carried out (http://www.evolvingcode. net/codon/CalculateCAIs.php; University of Maryland, Baltimore County, MD) to check if gpm was a glycolytic enzyme. The CAI analysis showed that this enzyme is probably not part of the glycolysis pathway (results not shown). This was also supported by the fact that the gpm gene was not a member of the gap operon (gapAl-pgktpiA-pgm-eno). Further work would be needed to elucidate the significance of this upregulation.

The expression of nine genes linked to electron transport was significantly changed by the acid shock. Among these were the three thioredoxin genes (trxAB and SACOL1794) discussed above and the $\mathrm{NADH}$ dehydrogenase gene (nuoF), and also two upregulated $\mathrm{NAD}(\mathrm{P}) \mathrm{H}$ oxidoreductase genes ( $f r p$ and SACOL0453).

Effects of acid shock on virulence and persistence factors. The acid shock did not seem to influence the induction of toxins, since most genes encoding toxins were down-regulated (Table 3, section C3). This is in accordance with their expected initiation at post-exponential growth. The active toxin in S. aureus 50583 is toxin B. SarA has been shown to upregulate both toxic shock syndrome toxin 1 gene ( $t s t$ ) expression and staphylococcal enterotoxin B production (Chan \& Foster, 1998). Neither the sarA gene nor the toxin B gene showed a significant change of expression level after the acid shock. The two-component system genes saeR and saeS, which are parts of the sae signalling locus involved in the regulation of many exoproteins (Novick \& Jiang, 2003), were both down-regulated (saeR 0.35 -fold and saeS 0.48 -fold after $20 \mathrm{~min})$. These results are consistent with those of Weinrick et al. (2004), which show that mild acid ( $3 \mathrm{~h}$ at $\mathrm{pH} 5.5$ ) reduces expression of sae genes 2.1-fold. For other regulators, the results were different, e.g. in the case of the rot (repressor of toxins) locus, for which we did not observe a downregulation of expression.

Besides the enterotoxins, a large number of other secreted proteins (haemolysins, proteases, lipases and coagulases) as well as cell-surface-associated proteins (protein $\mathrm{A}$, and fibrinogen-, fibronectin- and collagen-binding proteins) are essential for $S$. aureus pathogenicity. With the exceptions of a putative haemolysin gene (SACOL0762) and two pathogenicity island genes (SACOL0900 and SACOL0902), most virulence genes were down-regulated or showed no statistically significant change in expression ratio.

Of the genes directly related to drug resistance and detoxification of the cell, the genes encoding a Dps family protein (SACOL2131), alkaline-shock protein 23 and three drug-transporter genes were all upregulated. The asp23 gene, encoding the alkaline shock protein 23 , showed a somewhat unusual response in that it was first downregulated and then upregulated only after $20 \mathrm{~min}$. The pattern of expression remains unclear, since asp23 is reported to be under the control of $\sigma^{\mathrm{B}}$ (Giachino et al., 2001), which itself showed no change in expression. The upregulation of the putative drug-resistance transporter EmrB/QacA (SACOL2347 and SACOL2348) was at an especially high level, with factors of 12.1 and 15.5, respectively (Table 3 , section C2). The multidrug-resistance gene norA, the drug-transporter gene SACOL2460 and the bicyclomycin-resistance gene $b c r$ were all down-regulated.

For the extracellular enzymes, our results showed downregulation of staphylocoagulase precursor (SA0857), which is involved in clumping bacteria together as an antiphagocytic defence. Catalase, which protects the cells from being killed by polymorphonuclear leukocytes (PMNs), was (as mentioned above) clearly upregulated after acidification. Higher levels of catalase activity in virulent strains than in non-virulent strains of $S$. aureus have been found (Kanafani \& Martin, 1985). Nucleases are important for virulence in that they permit the reuse of bacterial and host nucleic acids. Several nucleases were found to be upregulated ( $u v r C, n t h, \operatorname{rex} A, \operatorname{rex} B)$, while some were down-regulated $(s b c D, r e c J, n f o)$.

The results indicated lack of adhesion and initiation of biofilm formation in the first $20 \mathrm{~min}$ following the acid 
shock. None of the major biofilm regulators $\operatorname{sig} B$, agr or sarA showed a statistically significant change in expression after the acid shock. The ica genes (icaADBC), known to be central to intercellular adhesion and biofilm formation, were all strongly down-regulated to a minimum ratio of 0.12-0.15. This was in accordance with the result obtained when cells were subjected to peracetic acid (Chang et al., 2006), but in contrast to work showing upregulation of the icaA and icaD genes when cells are grown at pH 5.5 (Weinrick et al., 2004). Two other adherence-associated genes, $f n b A$ (SACOL2511) and $f n b B$, encoding fibronectin-binding proteins $\mathrm{A}$ and $\mathrm{B}$, respectively, were down-regulated. The clfA gene, encoding clumping factor $\mathrm{A}$, mediates adherence to polyethylene and polyvinylchloride (Vaudaux et al., 1995), and showed a clear increase in expression from 10 to $20 \mathrm{~min}$ after the acid shock. The increase seen for clumping factor A could be an indication of adhesion after $20 \mathrm{~min}$, but further work is necessary to confirm this. It should be added that S. aureus 50583 produces relatively little biofilm compared to other S. aureus strains at $37^{\circ} \mathrm{C}$ (Rode et al., 2007).

Genes of unknown function. Among the 622 genes that showed a statistically significant change of expression level, $29(4.7 \%)$ encode enzymes of unknown specificity, $38(6.1 \%)$ encode proteins of unknown function and $133(21.4 \%)$ encode hypothetical proteins. Of the genes encoding hypothetical proteins, 59 (9.5\% of 622) were up- or down-regulated more than twofold and were included in Table 3 (section J3). Further work will be required to elucidate their role in the acid response.

\section{Conclusions}

Most responses showed an increase or decrease from time zero to $10 \mathrm{~min}$ after acidification and then generally a stabilization in expression level from 10 to $20 \mathrm{~min}$. Increased urease activity appears to be an important factor in the acid defence of $S$. aureus 50583, along with proton excretion by NADH dehydrogenase and macromoleculerepair mechanisms. Oxidative-stress responses, such as increased expression of thioredoxin genes and upregulation of PPP genes to generate more reducing power, were observed. A general reduction in the expression of genes encoding ribosomal proteins and genes involved in nucleotide synthesis, as well as fatty acid and lipoprotein metabolism, was typical, and reflected the lowered growth rate after acidification. Repair mechanisms and degradation of damaged proteins were induced. The acid shock did not initiate a virulence response. Many of the presented observations can be explained; some are unknown or cannot easily be interpreted. Nevertheless, together, these results show the main responses of $S$. aureus and will be a good starting point for future, more specific, in-depth studies of gene responses associated with the acid-stress defence of S. aureus.

\section{ACKNOWLEDGEMENTS}

This work was supported by the Fund for Research Levy on Agricultural Products (Norway) and the Norwegian Research Council project 159426/130. The S. aureus DNA arrays were obtained through the National Institute of Allergy and Infectious Diseases (NIAID) Pathogen Functional Genomics Resource Center, Division of Microbiology and Infectious Diseases, NIAID, National Institutes of Health. The authors acknowledge the assistance of Dr Lars Axelsson at Matforsk AS for performing the CAI analyses and for fruitful discussions.

\section{REFERENCES}

Arikado, E., Ishihara, H., Ehara, T., Shibata, C., Saito, H., Kakegawa, T., Igarashi, K. \& Kobayashi, H. (1999). Enzyme level of enterococcal $\mathrm{F}_{1} \mathrm{~F}_{0}$-ATPase is regulated by $\mathrm{pH}$ at the step of assembly. Eur J Biochem 259, 262-268.

Armstrong-Buisseret, L., Cole, M. B. \& Stewart, G. S. A. B. (1995). A homolog to the Escherichia coli alkyl hydroperoxide reductase $a h p C$ is induced by osmotic upshock in Staphylococcus aureus. Microbiology 141, 1655-1661.

Bauerfeind, P., Garner, R. M. \& Mobley, H. L. T. (1996). Allelic exchange mutagenesis of nixA in Helicobacter pylori results in reduced nickel transport and urease activity. Infect Immun 64, 2877-2880.

Beenken, K. E., Dunman, P. M., McAleese, F., Macapagal, D., Murphy, E., Projan, S. J., Blevins, J. S. \& Smeltzer, M. S. (2004). Global gene expression in Staphylococcus aureus biofilms. J Bacteriol 186, 4665-4684.

Brown, N. L., Stoyanov, J. V., Kidd, S. P. \& Hobman, J. L. (2003). The MerR family of transcriptional regulators. FEMS Microbiol Rev 27, 145-163.

Bunik, V. I. (2003). 2-Oxo acid dehydrogenase complexes in redox regulation - role of the lipoate residues and thioredoxin. Eur J Biochem 270, 1036-1042.

Burne, R. A. \& Chen, Y. Y. M. (2000). Bacterial ureases in infectious diseases. Microbes Infect 2, 533-542.

Chan, P. F. \& Foster, S. J. (1998). Role of SarA in virulence determinant production and environmental signal transduction in Staphylococcus aureus. J Bacteriol 180, 6232-6241.

Chang, W., Toghrol, F. \& Bentley, W. E. (2006). Toxicogenomic response of Staphylococcus aureus to peracetic acid. Environ Sci Technol 40, 5124-5131.

Chastanet, A., Derre, I., Nair, S. \& Msadek, T. (2004). clpB, a novel member of the Listeria monocytogenes CtsR regulon, is involved in virulence but not in general stress tolerance. J Bacteriol 186, 1165-1174.

Chatterjee, I., Becker, P., Grundmeier, M., Bischoff, M., Somerville, G. A., Peters, G., Sinha, B., Harraghy, N., Proctor, R. A. \& Herrmann, M. (2005). Staphylococcus aureus ClpC is required for stress resistance, aconitase activity, growth recovery, and death. J Bacteriol 187, 4488-4496.

Chedin, F. \& Kowalczykowski, S. C. (2002). A novel family of regulated helicases/nucleases from Gram-positive bacteria: insights into the initiation of DNA recombination. Mol Microbiol 43, 823-834.

Chen, Y. Y. M., Weaver, C. A., Mendelsohn, D. R. \& Burne, R. A. (1998). Transcriptional regulation of the Streptococcus salivarius 57.I urease operon. J Bacteriol 180, 5769-5775.

Clements, M. O. \& Foster, S. J. (1999). Stress resistance in Staphylococcus aureus. Trends Microbiol 7, 458-462. 
Clements, M. O., Watson, S. P. \& Foster, S. J. (1999). Characterization of the major superoxide dismutase of Staphylococcus aureus and its role in starvation survival, stress resistance, and pathogenicity. J Bacteriol 181, 3898-3903.

Cohen, S. P., Hachler, H. \& Levy, S. B. (1993). Genetic and functional analysis of the multiple antibiotic-resistance (mar) locus in Escherichia coli. J Bacteriol 175, 1484-1492.

Cotter, P. D. \& Hill, C. (2003). Surviving the acid test: responses of Gram-positive bacteria to low pH. Microbiol Mol Biol Rev 67, 429-453.

Davis, G. S. \& Mobley, H. L. T. (2005). Contribution of $d p p A$ to urease activity in Helicobacter pylori 26695. Helicobacter 10, 416-423.

Deora, R., Tseng, T. \& Misra, T. K. (1997). Alternative transcription factor $\sigma^{\mathrm{SB}}$ of Staphylococcus aureus: characterization and role in transcription of the global regulatory locus sar. J Bacteriol 179, 6355-6359.

Epstein, W. (2003). The roles and regulation of potassium in bacteria. Prog Nucleic Acid Res Mol Biol 75, 293-320.

Foster, J. W. (2004). Escherichia coli acid resistance: tales of an amateur acidophile. Nat Rev Microbiol 2, 898.

Frees, D., Chastanet, A., Qazi, S., Sorensen, K., Hill, P., Msadek, T. \& Ingmer, H. (2004). Clp ATPases are required for stress tolerance, intracellular replication and biofilm formation in Staphylococcus aureus. Mol Microbiol 54, 1445-1462.

Giachino, P., Engelmann, S. \& Bischoff, M. (2001). $\sigma^{\mathrm{B}}$ activity depends on RsbU in Staphylococcus aureus. J Bacteriol 183, 1843-1852.

Greenberg, J. T., Monach, P., Chou, J. H., Josephy, P. D. \& Demple, B. (1990). Positive control of a global antioxidant defense regulon activated by superoxide-generating agents in Escherichia coli. Proc Natl Acad Sci U S A 87, 6181-6185.

Hofmann, B., Hecht, H. J. \& Flohe, L. (2002). Peroxiredoxins. Biol Chem 383, 347-364.

Horsburgh, M. J., Clements, M. O., Crossley, H., Ingham, E. \& Foster, S. J. (2001). PerR controls oxidative stress resistance and iron storage proteins and is required for virulence in Staphylococcus aureus. Infect Immun 69, 3744-3754.

Kanafani, H. \& Martin, S. E. (1985). Catalase and superoxidedismutase activities in virulent and nonvirulent Staphylococcus aureus isolates. J Clin Microbiol 21, 607-610.

Kisker, C., Schindelin, H. \& Rees, D. C. (1997). Molybdenumcofactor-containing enzymes: structure and mechanism. Annu Rev Biochem 66, 233-267.

Kobayashi, H., Miyamoto, T., Hashimoto, Y., Kiriki, M., Motomatsu, A., Honjoh, K. \& lio, M. (2005). Identification of factors involved in recovery of heat-injured Salmonella Enteritidis. J Food Prot 68, 932-941.

Kuroda, M., Kuroda, H., Oshima, T., Takeuchi, F., Mori, H. \& Hiramatsu, K. (2003). Two-component system VraSR positively modulates the regulation of cell-wall biosynthesis pathway in Staphylococcus aureus. Mol Microbiol 49, 807-821.

Langsrud, O. (2005). Rotation tests. Stat Comput 15, 53-60.

Lasken, R. S. \& Kornberg, A. (1988). The primosomal protein $\mathrm{N}^{\prime}$ of Escherichia coli is a DNA helicase. J Biol Chem 263, 5512-5518.

Len, A. C., Harty, D. W. S. \& Jacques, N. A. (2004). Proteome analysis of Streptococcus mutans metabolic phenotype during acid tolerance. Microbiology 150, 1353-1366.

Lowy, F. D. (1998). Medical progress - Staphylococcus aureus infections. N Engl J Med 339, 520-532.

Ma, J. F., Hager, P. W., Howell, M. L., Phibbs, P. V. \& Hassett, D. J. (1998). Cloning and characterization of the Pseudomonas aeruginosa $z w f$ gene encoding glucose-6-phosphate dehydrogenase, an enzyme important in resistance to methyl viologen (paraquat). J Bacteriol 180, 1741-1749.

Manna, A. C., Bayer, M. G. \& Cheung, A. L. (1998). Transcriptional analysis of different promoters in the sar locus in Staphylococcus aureus. J Bacteriol 180, 3828-3836.

Maurer, L. M., Yohannes, E., Bondurant, S. S., Radmacher, M. \& Slonczewski, J. L. (2005). pH regulates genes for flagellar motility, catabolism, and oxidative stress in Escherichia coli K-12. J Bacteriol 187, 304-319.

Miyazaki, E., Chen, J. M., Ko, C. \& Bishai, W. R. (1999). The Staphylococcus aureus rsbW (orf159) gene encodes an anti-sigma factor of SigB. J Bacteriol 181, 2846-2851.

Mobley, H. L. T., Garner, R. M. \& Bauerfeind, P. (1995). Helicobacterpylori nickel-transport gene nixA - synthesis of catalytically active urease in Escherichia coli independent of growth-conditions. Mol Microbiol 16, 97-109.

Moen, B., Oust, A., Langsrud, O., Dorrell, N., Marsden, G. L., Hinds, J., Kohler, A., Wren, B. W. \& Rudi, K. (2005). Explorative multifactor approach for investigating global survival mechanisms of Campylobacter jejuni under environmental conditions. Appl Environ Microbiol 71, 2086-2094.

Novick, R. P. \& Jiang, D. R. (2003). The staphylococcal saeRS system coordinates environmental signals with agr quorum sensing. Microbiology 149, 2709-2717.

Nurse, P., Zavitz, K. H. \& Marians, K. J. (1991). Inactivation of the Escherichia coli PriA DNA-replication protein induces the SOS response. J Bacteriol 173, 6686-6693.

Paget, M. S. B., Molle, V., Cohen, G., Aharonowitz, Y. \& Buttner, M. J. (2001). Defining the disulphide stress response in Streptomyces coelicolor A3(2): identification of the $\sigma^{\mathrm{R}}$ regulon. Mol Microbiol 42, 1007-1020.

Pallen, M. J. \& Wren, B. W. (1997). The HtrA family of serine proteases. Mol Microbiol 26, 209-221.

Palma, M. \& Cheung, A. L. (2001). $\sigma^{\mathrm{B}}$ activity in Staphylococcus aureus is controlled by RsbU and an additional factor(s) during bacterial growth. Infect Immun 69, 7858-7865.

Quiberoni, A., Rezaiki, L., El Karoui, M., Biswas, I., Tailliez, P. \& Gruss, A. (2001). Distinctive features of homologous recombination in an 'old' microorganism, Lactococcus lactis. Res Microbiol 152, 131-139.

Rode, T. M., Langsrud, S., Holck, A. \& Møretrø, T. (2007). Different patterns of biofilm formation in Staphylococcus aureus under foodrelated stress conditions. Int J Food Microbiol 116, 372-383.

Tsau, J. L., Guffanti, A. A. \& Montville, T. J. (1992). Conversion of pyruvate to acetoin helps to maintain $\mathrm{pH}$ homeostasis in Lactobacillus plantarum. Appl Environ Microbiol 58, 891-894.

Uziel, O., Borovok, I., Schreiber, R., Cohen, G. \& Aharonowitz, Y. (2004). Transcriptional regulation of the Staphylococcus aureus thioredoxin and thioredoxin reductase genes in response to oxygen and disulfide stress. J Bacteriol 186, 326-334.

Valenzuela, M., Cerda, O. \& Toledo, H. (2003). Overview on chemotaxis and acid resistance in Helicobacter pylori. Biol Res 36, 429-436.

van Vliet, A. H. M., Kuipers, E. J., Waidner, B., Davies, B. J., de Vries, N., Penn, C. W., Vandenbroucke-Grauls, C. M., Kist, M., Bereswill, S. \& Kusters, J. G. (2001). Nickel-responsive induction of urease expression in Helicobacter pylori is mediated at the transcriptional level. Infect Immun 69, 4891-4897.

Vaudaux, P. E., Francois, P., Proctor, R. A., McDevitt, D., Foster, T. J., Albrecht, R. M., Lew, D. P., Wabers, H. \& Cooper, S. L. (1995). Use of 
adhesion-defective mutants of Staphylococcus aureus to define the role of specific plasma proteins in promoting bacterial adhesion to canine arteriovenous shunts. Infect Immun 63, 585-590.

Weinrick, B., Dunman, P. M., McAleese, F., Murphy, E., Projan, S. J., Fang, Y. \& Novick, R. P. (2004). Effect of mild acid on gene expression in Staphylococcus aureus. J Bacteriol 186, 8407-8423.
Wilkins, J. C., Homer, K. A. \& Beighton, D. (2002). Analysis of Streptococcus mutans proteins modulated by culture under acidic conditions. Appl Environ Microbiol 68, 2382-2390.

Wood, J. M. (1999). Osmosensing by bacteria: signals and membranebased sensors. Microbiol Mol Biol Rev 63, 230-262.

Edited by: J. Green 